\title{
Processes Standardization: A Case Study in the Form of Supply in a Company of the Two Wheels of Manaus
}

\author{
Nayara Oliveira S. Santos, Jennifer Yassumi Ishida, Marcelo Albuquerque de Oliveira, \\ Gabriela de Mattos Veroneze, Dércio Luiz Reis, and Joaquim Maciel da Costa Craveiro
}

\section{ABSTRACT}

\begin{abstract}
This article aims to study the application of standardization techniques in a two-wheel hub company in the city of Manaus, more specifically in the subassembly sector of the chassis, responsible for the preparation of parts to supply the assembly line. The methodologies used were the $5 \mathrm{~S}$ methodology, which is proven very effective in identifying and eliminating waste and increasing efficiency; the standardization of intermediate stock, to improve the performance of the purchasing and business sectors, and finally, the PDCA cycle, to identify needs and find suitable, low-cost solutions. From the data collected, the problem was defined as the three worst parts, which are the mudguard, rear fork, and top cover, as it was found that they are recurrent in more than $50 \%$ of the models produced. These defects are due to the improper storage of the parts, which present scratches and beat marks. The need to establish an ideal condition of ideal storage was raised, and a manual was elaborated in which basic actions are listed to avoid small defects. After applying the mentioned tools and methodologies, the company managed to reduce the occurrence of small defects.
\end{abstract}

Keywords: Processes, Reliability, Standardization, Supply Chain.

\author{
Submitted : September 11, 2021 \\ Published : November 30, 2021
}

ISSN: $2507-1076$

DOI: $10.24018 /$ ejbmr.2021.6.6.1105

Nayara Oliveira S. Santos*

Graduation student in Production Engineering, Federal University of Amazonas.

(e-mail: kucknayara@gmail.com)

Jennifer Yassumi Ishida

Graduation student in Production Engineering, Federal University of Amazonas.

(e-mail: Jennifer.ishida ${ }^{\circledR}$ gmail.com)

Marcelo de Albuquerque de Oliveira

Professor, PhD, Master's Program in Production Engineering, Federal University of Amazonas.

(e-mail: marcelooliveira@ufam.edu.br)

Gabriela de Mattos Veroneze

Professor, PhD, Master's Program in

Production Engineering, Federal University of Amazonas.

(e-mail: gveroneze@ufam.edu.br)

Dercio Luiz Reis

Professor, PhD, Master's Program in Production Engineering, Federal University of Amazonas.

(e-mail: dercioreis@ ufam.edu.br)

Joaquim Maciel da Costa Craveiro

Professor, PhD, Master's Program in

Production Engineering, Federal University of

Amazonas.

(e-mail: jmaciel@ufam.edu.br)

*Corresponding Author

\section{INTRODUCTION}

Improving or keeping the competitiveness nowadays is a considerable challenge, taking into account the existence of many factors that impact on the awaited results and that once were not considered due to the total focus in its own production of goods/services. There are other factors within the organizations that affect this competitiveness, which if they are treated in a way to improve their results can affect directly in the company's objective outreach.

For example, analyzing the materials' movement through the chain, it is observed with relative ease that this activity is in almost all the production steps of any item. Resources such as materials, labor and equipment need to be properly managed to guarantee a production at lower costs and adequate quality.
In view of that, it has concluded that a considerable portion of time, physical space and human resources acts directly with materials aiming to assist the intern and extern clients. These features highlight that this activity is strategic, and that such as the final productive process must also be realized as real opportunities of enhancement to achieve goals.

The current work is about the supply of subassembly pieces to the main motorcycles' mounting line for a company from Manaus Industrial Pole. The principal objective of this study is the implantation of these improvements such as establish a conformity pattern on the materials sending and hereafter the implantation of a "pulled" system of these items, through techniques and tools that guarantee reliability to the system obeying to the production principle "shuku-shuku", from Japanese, who means "continuous production," "stable". According to Rocha et al. (2014), it's necessary for the creation of a continuous production stream, that the support processes must be aligned with the culture of waste 
elimination and capable of supplying only what the next step will consume on lower time intervals.

In order to achieve the objective, the research proposes itself to understand the materials' stream (intern logistical system, lead time within production lines and need of intermediate stock) to identify the improvement opportunities and possible gains. The proposed theme aims to increase the security and reliability operation levels, following the subjects on the Task.

\section{LITERATURE REVIEW}

\section{A. 5S Methodology}

With economic climate in constant change, many organizations adjust periodically their resources to align to the business strategies. This usually results in the need of doing more work with fewer resources. To keep wellsucceeded, the companies must become more efficient, reduce waste and this way, reduce costs (Juran, 1992).

According to Neves (2002), one way to do that is by using the $5 \mathrm{~S}$ principle. The $5 \mathrm{~S}$ methodology is very efficient in identification and elimination of wastes and in the efficiency increase.

Synthetically, the $5 \mathrm{~S}$ is a standardization of processes that, when correctly implemented, creates and maintains an organized workplace, secure, clean and efficient. The $5 \mathrm{~s}$ is frequently an element that provides a continuous enhances. The 5S list is the following (Neves, 2002):

- Seiri (sort): Separating the essential items from the non-essential;

- Seiton (set in order): Organizing the essential materials where everything has its place;

- Seiso (shine): Cleaning the workplace;

- Seiketsu (standardize): Establishing a system to keep and turn $5 \mathrm{~S}$ a habit;

- Shitsuke (sustain): Establishing an environment of work safe and hygienic.

On the industries, the $5 \mathrm{~S}$ principles are seen as basic items to guarantee quality, being defined in the mounting sector as the basis to the "way of producing" of the company studied. Thus, the tools are efficient to improve the organization of the workplace, reducing the waste and improving the efficiency (Neves, 2002).

In this context, to the company adequate itself to $5 \mathrm{~S}$ it is important to create a standardization supplies chain process in its business units.

The underlying supposition is that the standardization will reduce costs and improve the capacity of response. If a company considers its supply standardization a "cost", so it makes all sense to reduce it to the minimum possible. Although, most companies consider the supply chain not as an issue to be faced, but as a competitiveness tool to increase profit (Ballou, 2003).

Furthermore, due to its ease of implementation, the $5 \mathrm{~S}$ methodology is widely used in various processes where it is intended to identify opportunities for improvement (Ahuja and Khamba, 2008; Indrawati et al., 2020; Lopes et al., 2015; Sahoo and Yadav, 2018).

\section{B. Intermediate Stock Standardization}

The supply standardization is a development and implementation process of technic patterns. The process has established a common deal to the criteria, terms, principles, practices, materials, items, processes, pieces, and compounds of engineering equipment (Ballou, 2003).

Therefore, in the two wheels pole-mounting sector, the supply standardization must be better tracked. The requests must be automated, and technology enhanced. These items can assist in supply standardization.

Clearly, much money can be saved by standardization, applying protocols and, thus, reducing the number of products that need to be stocked and using these products efficiently (Ayres, 2014).

In this configuration, supply standardization of the two wheels hub has the main line and the subassembly. The subassembly prepares the pieces and sends them to the main line and, so, mounts the motorcycles. This subassembly supply is done irregularly. The only thing patterned is the quantity of pieces to basic items. The idea is to pattern these supplies.

It's important to understand that each situation, there are two compounds to standardization. The first is the generic processes standardization of supplies chains that covers all the sectors. The second is about the specific industry features that involve the restructuring of business processes to use supplies chain efficiently. And thus, avoid supplies irregularly (Ballou, 2003).

Face to what has been exposed, the standardization reliability is a valuable tool to reduce the supply-chain costs, but the true issue is to discover how the supply chain can be configured to offer support more efficient to the business objectives. In case of the mounting sector of the two wheels hub, simplifying the stopped pieces would be a good option.

Finally, many studies show that the implementation of materials and procedures' standardization of purchases (purchases standardization) can assist the organizations to improve the performance of purchases and business. An efficient purchase function consists of a business process of key trades in the supplies chain.

The importance of stock management is fundamental to the control of stock and costs in organizations, according to the works of different authors, as a cost competitiveness factor (Assunção et al., 2017; Bylka, 2020; Haijema and Minner, 2019; Kabir and Al-Olayan, 1996).

\section{Quality and Reliability}

Quality is when a product or service assists perfectly the consumer, in an accessible way, secure, reliable and in the right time to the customer 's needs (Montgomery, 2020). The quality can be realized through distinct optics. For example, through a product (characteristics of the product), consumed (based upon your satisfaction), product (if it is within the standards and specifications), through the value (price) and as an abstract concept incorporating the corporation values.

In Brazil, the actions focused on quality started in the 90s, through the implementation of management systems developed in Japan, such as Total Quality Control - TQC, Total Productive Maintenance $1-$ TPM and Lean Manufacturing. 
According to the technical standards NBR-5462, reliability can be defined as the probability of certain equipment, system or compound doing its activities without failures in a certain period and conditions specified, thus, it is related to the medium rate of failures of defects (Paulinio, 2014).

Therefore, reliability is one of the "dimensions "of quality (Bylka, 2020), being the reliability level directly dependent on the maturity level that a certain company has over its activities and analysis to problem solving, depends on the use efficiency of its resources, not only physical but also human (Bertolini et al., 2006; Rausand and Øien, 1996; Sharma and Sharma, 2014; Zio et al., 2019).

\section{MethodolOGY}

The methodological procedure used in this work has been the PCDA cycle, taking into account the objectives to identify potential failures quantitatively, through indexes and average of defects, with the aim to elaborate a pattern procedure to the problem of the study case. Thus, it's expected to identify the needs to find adequate solutions and of low cost.

To the data collection, it has been searched through bibliographic researches on books, periodicals and on the available material in the virtual environment of the research class TASK - WP3 from the Super Project, the formation of basic knowledge about the standardization theme aiming to justify the proposed actions' applicability. It has been done in loco observation of processes belonged to a motorcycle factory of Manaus Hub.

This observation was necessary to understand the critical weakness from the processes and the need of standardization of it, with the purpose to achieve the goals determined by the factory, for that it was used a Pareto Chart to define the issues that this research will develop actions to solve it.

\section{RESULTS AND DISCUSSIONS}

The company of the study case is a motorcycle factory that operates for more than 50 years in Manaus free zone, employs more than 2 thousand collaborators and produces an average of 10 models daily. Its headquarters in Japan has more than 134 years of action in the market.

It has been the first manufacturer of motorcycles in the country and within its huge quantity of products also presents articles to the nautical universe, besides other many solution options to the client.

The studied sector was the subassembly of the chassis. This sector does the preparation (subassembly) of pieces to supply the mounting line. Some examples of the activities done are screw placement, screws and buffers fixation, gas tanks mounting and realization of leakage tests.

The sector counts on more than 80 collaborators distributed in 10 workplaces. The motorcycle mounting process is given by the following stream, as it is shown in Fig. 1.

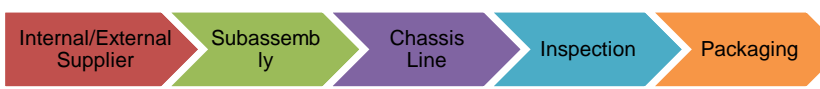

\section{A. Current Situation}

A process with quality occurs when the efficient integration of the operations and activities that compound a process.

The more common way to measure quality process is the percentage of unites not in accordance or defective, thus the data collected to have been calculated by the index of a defect by piece.

Initially, to the delimitation of the work, through the research in the quality team historic problems it has been surveyed the most critical pieces from the period of January to June of 2020, as it is shown in Fig. 2.

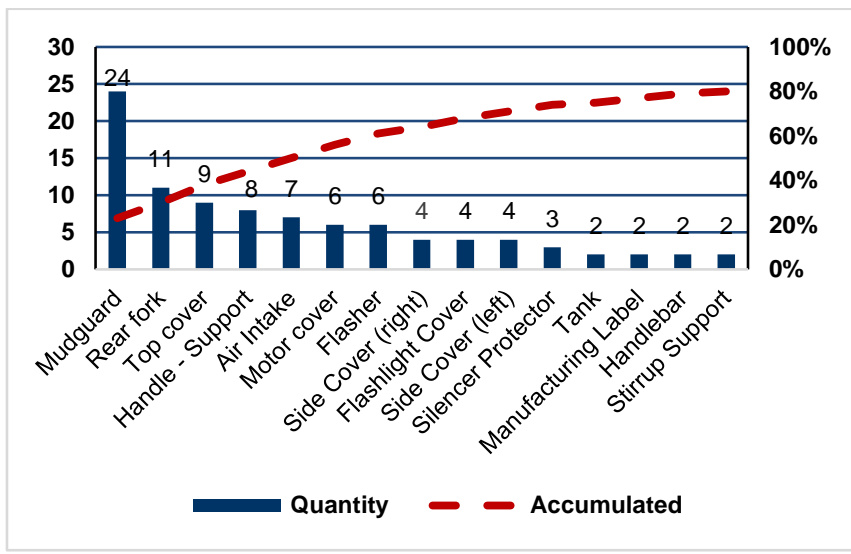

Fig. 2. Accumulating defects by Pieces (January - June).

From these data, it has been delimited if the problem such as the three worst pieces (streamline fender, rear fork and superior cover), because in analysis of the team's history problem of small defects that analyses the beaten and crossed out, it has been observed that they are recurrent in more than $50 \%$ of the produced models, once it's exposed, the projection of these items would be the goal achievement, once the three pieces are responsible for $0,2 \%$ of the losses in the index.

Forthwith, it has been chosen to conduct a quantitative analysis of the recurrence of defects on paid cars and the physical space that divides sectors, to understand, which is the source that causes the root of the problems, if it comes from the "sub" or in the Chassis' line.

The Fig. 3 shows the result of this inspection of the selected pieces as priority.

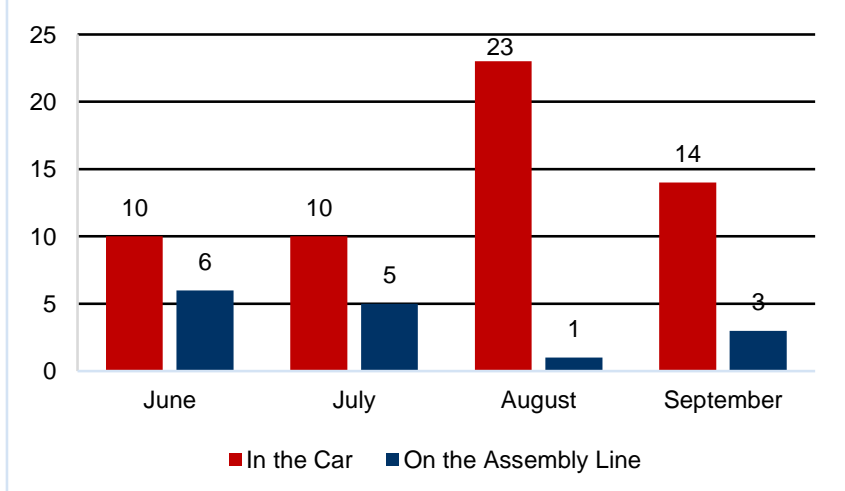

Fig. 3. Number of Items out of Specified.

Fig. 1. Motorcycle Assembly Process. 


\section{B. Actions Proposed}

By observing the storage conditions to posterior feed of the line, it has been noticed that sometimes a certain piece came with a type of car with a certain quantity of pieces by shelves, and eventually it came from a different car with different quantity of pieces superimposed.

Within the opportunity, it has been observed that this supply without pattern generates the defects of the type a beaten and crossed out, once depending on the storage type of the stock the pieces can collide with each other and in the insertion and removal of the piece, it ends up being in contact with the car shelves.

During the analysis, it has been evaluated the need of establishing an ideal storage condition, with the quantity definition, size, spacing, and car type to each piece.

Such as it is exemplified the following Table I, that relates the needed quantity to buffer, car capacity and which car type to each piece.

\begin{tabular}{|c|c|c|c|c|c|c|c|}
\hline \multicolumn{8}{|c|}{ Quantity of Carrier Cars per Pieces } \\
\hline \multicolumn{8}{|c|}{ Motorcycle Model XXX } \\
\hline ST & Piece & Buffer & Capacity & Fork & Wood & Cloth & Tubular \\
\hline 11 & $\begin{array}{c}\text { Front } \\
\text { suspension }\end{array}$ & 25 & 10 & & & & 4 \\
\hline \multirow[t]{2}{*}{12} & Rear fork & 25 & 5 & 4 & & & \\
\hline & Air filter & 25 & 50 & & & 2 & \\
\hline \multirow[t]{2}{*}{13} & Brake pedal & 25 & 30 & & & 3 & \\
\hline & Side Easel & 25 & 30 & & 3 & & \\
\hline \multirow[t]{2}{*}{14} & Handlebar table & 25 & 50 & & & 2 & \\
\hline & $\begin{array}{c}\text { Hoses } \\
\text { assembly }\end{array}$ & 25 & 25 & & 3 & & \\
\hline \multirow[t]{3}{*}{15} & $\begin{array}{l}\text { Right/Left } \\
\text { stirboaard }\end{array}$ & 25 & 50 & & & 4 & \\
\hline & Handlebars set & 25 & 50 & & & 2 & \\
\hline & Air duct & 25 & 100 & & & 1 & \\
\hline 16 & License support & 25 & 12 & & & 4 & \\
\hline \multirow[t]{2}{*}{17} & Rear mend & 30 & 25 & & & 3 & \\
\hline & Tank top cover & 30 & 25 & & & 3 & \\
\hline 18 & Lighthouse set & 25 & 50 & & & 2 & \\
\hline 19 & Tank set & 25 & 24 & & 3 & & \\
\hline 20 & $\begin{array}{l}\text { Right/Left air } \\
\text { inlet }\end{array}$ & 30 & 25 & & & 6 & \\
\hline \multicolumn{4}{|c|}{ Total } & 4 & 9 & 32 & 4 \\
\hline \multicolumn{4}{|c|}{ Current } & 4 & 11 & 33 & 8 \\
\hline \multicolumn{4}{|c|}{ Necessity } & 0 & -2 & -1 & \\
\hline
\end{tabular}

Besides the ideal condition survey, there has been elaborated a manual containing seven basic actions to avoid the occurrence of small defects, which has mapped all the root cause and proposed a behavioral action to each causal type so that we can raise the human reliability and process level. Besides, pattern the cars with identification forms with the correct way of supply, as shown in the following Fig. 4.

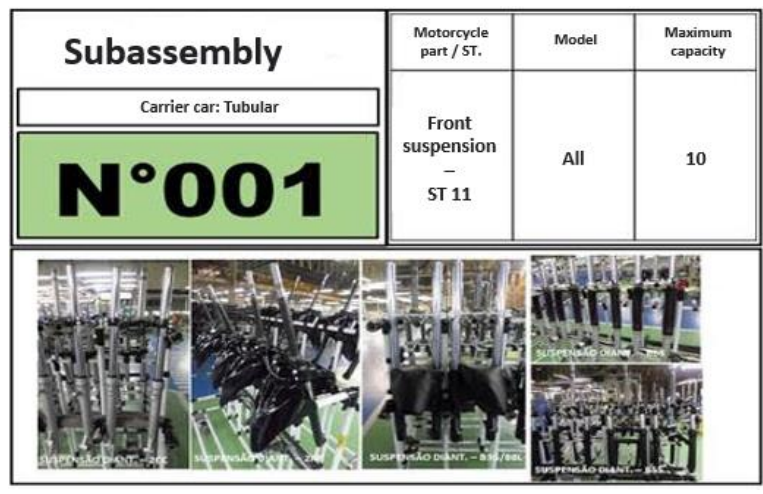

Fig. 4. Identification forms of the Carrier Cars.
It can be verified, by the results presented in the following graphic, that the chosen method to analysis of problem solving is very efficient in the process management. The study case has ascertained that, by the tools' choices and adequate methodologies to the process analysis.

The company has achieved the monthly goal of small defects, reducing expressly the occurrences in the analyzed pieces. The result is shown in the Fig. 5.

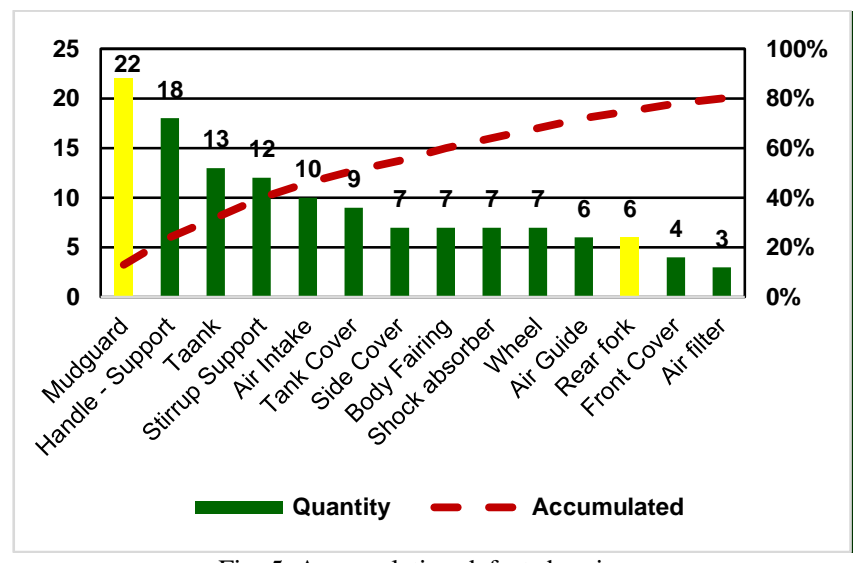

Fig. 5. Accumulating defects by piece.

Besides that, through the ideal condition, it can be identified the need of acquisition of more cars to attend to the production demand.

It is important to highlight that the work has been done by the team's orientation over the reliability as a method to achieve quality, because through the reliability models, it can be seen clearly the weak spots of any process and treat action planned to decrease failures, including human failures arising from many variables, not only the supply way in the cars that hasn't been subjects of this analysis.

\section{CONCLUSIONS}

The current work highlighted the concordance between methods and tools, over a theoretical-practical view.

It directs, to new studies: in the analyzed company, for example, the utilization of Lean Manufacturing or IoT (Internet of Things), to intermediate stock elimination ("buffer") between preparing and assembly sectors.

In this sense, the management activity and its wastes must decide by managers in which levels of stocks are economically able to maintain.

It is understood that the objective proposed in this work has been achieved, because it has presented the pieces supplied to the main line in a motorcycle industry, which has been highlighted through tools used in its strong spots, also as the losses of enhancement opportunities.

\section{ACKNOWLEDGMENT}

The authors thank the Production Engineering Department (DEP) of the Federal University of Amazonas (UFAM) for their support and structure.

Special acknowledgement to the institutions and people involved to the final consolidation of this work that has been authorized through the agreement 001/2020 from the Cooperação Técnico-Científica celebrated between Fundação 
Universidade do Amazonas (FUA), Fundação de Apoio ao Ensino, Pesquisa, Extensão e Interiorização do IFAM (FAEPI) and the company Samsung Eletrônica da Amazônia LTDA (SEDA-M), within the project's scope of capacitation and research, which has been done by the academic unity FTUFAM.

\section{REFERENCES}

Ahuja, I. P. S., and Khamba, J. S. (2008). Strategies and success factors for overcoming challenges in TPM implementation in Indian manufacturing industry. J. Oual. Maint. Eng., 14(2), 123-147.

Assunção, F., Monteiro, M., Guilherme, J., Martis, C., Mariz, K. (2017). Analysis of stock management in a supply chain with focus on Lean Office Guidelines. Revista Brasileira de Gestão, Negócios e Tecnologia da Informação, 2, 62-71.

Ayres, A., Sucupira, C., and Accioly, F. (2014). Gestão de Estoques. $1^{\text {st }}$ ed. São Paulo: FGV Editora, 133 p.

Ballou, R. H. (2003). Business Logistics/Supply Chain Management and Logware CD Package. 5a ed., Prentice Hall, 816 p.

Bertolini, M., Bevilacqua, M., and Mason, G. (2006). Reliability design of industrial plants using Petri nets. J. Qual. Maint. Eng., 12(4), 397-411.

Bylka, S. (2020). The consignment stock of inventories under buyer's warehouse space limitation. Int. J. Prod. Res., 58(3), 912-930.

Haijema, R., and Minner, S. (2019). Improved ordering of perishables: The value of stock-age information. Int. J. Prod. Econ., 209, 316-324.

Indrawati, S., 'Azzam, A., Adrianto, E., Miranda, S., and Prabaswari, A. D. (2020). Lean Concept Development in Fast Food Industry Using Integration of Six Sigma and TRIZ Method. IOP Conf. Ser. Mater. Sci. Eng., $722,012044$.

Juran, J. M. Juran on quality by design: the new steps for planning quality into goods and services. Simon and Schuster, 1992.

Kabir, A. B. M. Z., and Al-Olayan, A. S. (1996). A stocking policy for spare part provisioning under age based preventive replacement. Eur. J. Oper. Res., 90(1), 171-181.

Lopes, R. B., Freitas, F. and Sousa, I. (2015). Application of lean manufacturing tools in the food and beverage industries. J. Technol. Manag. Innov., 10(3), 120-130.

Montgomery, D. C. (2020). Introduction to Quality Statistic Control. Wiley; eighth edition, $768 \mathrm{p}$.

Neves, J. N. D. R. (2002). Avaliação de um modelo de gestão da qualidade segundo os princípios sistêmico, endógeno e distintivo de competitividade: um estudo de caso.

Paulinio, M. E. (2014). Considerações sobre manutenção aspectos relacionados à manutenção de equipamentos e de instalações. 97, p. 8 .

Rausand, M., and Øien, K. (1996). The basic concepts of failure analysis. Reliab. Eng. Syst. Saf., 53(1), 73-83.

Rocha, A., Mota, E., Junior, I., and Quintella, O. (2014). Gestão da Qualidade e Processos. 1st ed. São Paulo: FGV Editora, ISBN: $9788522509683,169 \mathrm{p}$.

Sahoo, S., and Yadav, S. (2018). Lean production practices and bundles: a comparative analysis. Int. J. Lean Six Sigma, 9(3), 374-398.

Sharma, R. K., and Sharma, R. G. (2014). Integrating six sigma culture and TPM framework to improve manufacturing performance in SMEs. Qual. Reliab. Eng. Int., 30(5), 745-765.

Zio, E., Fan, M., Zeng, Z., and Kang, R. (2019). Application of reliability technologies in civil aviation: Lessons learnt and perspectives. Chinese J. Aeronaut., 32(1), 143-158.

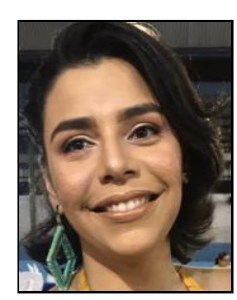

Nayara Oliveira S. Santos is a student of Production Engineering at the Federal University of Amazonas, and researcher under SUPER project.

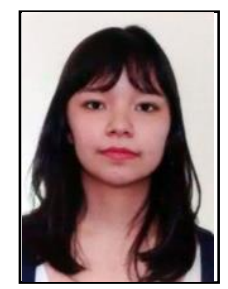

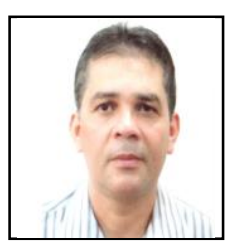

Marcelo Oliveira is an Adjunct Professor of Department of Production Engineering and member of Master Program in Production Engineering, Federal University of Amazonas. He has published several Research Papers related to Engineering area.

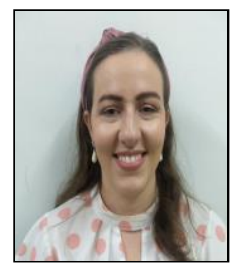

Gabriela Veroneze is an Adjunct Professor, Department of Production Engineering and member of Master Program in Production Engineering, Federal University of Amazonas. She has published several Research Papers related to Engineering area.

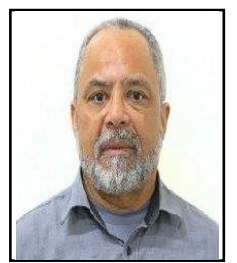

Dércio Reis is an Adjunct Professor, Department of Production Engineering and member of Master Program in Production Engineering, Federal University of Amazonas. $\mathrm{He}$ has published several Research Papers related to Engineering area.

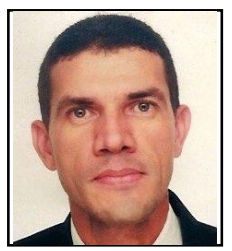

Joaquim Craveiro is an Adjunct Professor, Department of Production Engineering and member of Master Program in Production Engineering, Federal University of Amazonas. $\mathrm{He}$ has published several Research Papers related to Engineering area. 